\title{
COMPARATIVE STUDY BETWEEN THE EFFECT OF INTRATHECAL BUPIVACAINE AND INTRATHECAL BUPIVACAINE-MIDAZOLAM ON POST-OPERATIVE ANALGESIA
}

\author{
By \\ Ahmed Tharwat Mosallam Asfour, Mona Hanem Abd El-Ghaffar \\ Ahmed and Nasr Abd Al-Aziz Mohammed Saad \\ Anesthesiology and Intensive Care Department, Faculty of Medicine, Al-Azhar University \\ Corresponding Author: Ahmed Tharwat Mosallam Asfour \\ E-mail: ahmedasfour551@gmail.com
}

\begin{abstract}
Background: The central neuroaxial blockade is one of the most important and most commonly used regional anesthetic techniques for lower abdominal, perineal and lower limb surgeries. Administration of combinations of drugs intrathecal targeting multiple spinal cord receptors leads to prolonged analgesia with superior quality. This can be achieved by relatively small concentrations of individual drugs.

Objective: To compare the efficacy of intrathecal bupivacaine versus intrathecal bupivacaine-midazolam on post-operative analgesia.

Patients and Methods: This prospective randomized study was carried out on 60 patients. They were divided into two equal groups: bupivacaine group and bupivacaine-midazolam group and compare the effect of both groups on post-operative analgesia. They were admitted to Hospital for elective lower abdominal, perineal and lower limb surgeries. The study was conducted at Al-Azhar University Hospitals, from August 2019 till July 2020.

Results: The duration of post-operative analgesia was longer in the bupivacaine midazolam group (152.5 \pm 20.44 minutes) compared to the bupivacaine only group (120.0 \pm 31.54 minutes), but onset of sensory block was $1.55 \pm 0.48$ minutes in the bupivacaine only group, and $1.56 \pm 0.55$ minutes in bupivacaine midazolam group. There were no statistically significant differences in the two groups as regard onset of motor block, duration of motor block and there effect on postoperative nausea and vomiting.
\end{abstract}

Conclusion: The addition of midazolam to bupivacaine in spinal anesthesia resulted in prolonged postoperative analgesia with no significant increase in the duration of motor block.

Keywords: Intrathecal, Bupivacaine, Midazolam, Post-operative analgesia.

\section{INTRODUCTION}

The dose reductions may avoid drugrelated side effects. In addition, the simultaneous targeting of several different receptor sites in the spinal cord may lead to improved pain relief (Stein, 2018). There are many drugs for spinal anesthesia, each having its own advantages and disadvantages. There has been growing emphasis on the advantages of combined pharmacological approach for pain relief. Discovery of analgesic effects of spinally administered opioids and other drugs such as benzodiazepines and alpha-2 adrenoreceptor agonists has 
opened the possibilities of optimizing on useful drug interactions at the level of spinal cord in the management of pain (Cowen et al., 2015). Intra-thecal midazolam reduces excitatory $\gamma$ aminobutyric acid-mediated neurotransmission in interneuron, leading to a decrease in the excitability of spinal dorsal horn neurons. Moreover, it causes the release of an endogenous opioid that acts at the spinal delta receptor. So, it can potentiate the effect of intrathecal bupivacaine and enhance the intraoperative anaesthesia and analgesia in addition to postoperative analgesia (Tesfaye et al., 2013).

The present work aimed to compare the efficacy of intrathecal bupivacaine versus intrathecal bupivacaine-midazolam on post-operative analgesia.

\section{PATIENTS AND METHODS}

This prospective randomized study was carried out on 60 patients admitted to Hospital for elective lower abdominal, perineal and lower limb surgeries. The study was conducted at Al-Azhar University Hospitals from August 2019 till July 2020. After approval from ethical committee, informed consents were obtained from all patients.

\section{Patients were divided into 2 equal groups:}

Group A (control group) was given $3.5 \mathrm{ml}$ of $0.5 \%$ hyperbaric bupivacaine plus $0.4 \mathrm{ml}$ saline $0.9 \%$.

Group B (study group) was given $3.5 \mathrm{ml}$ of $0.5 \%$ hyperbaric bupivacaine plus $2 \mathrm{mg}$ $(0.4 \mathrm{ml})$ of $0.5 \%$ midazolam.

\section{Inclusion criteria:}

- Patients with ASA I -II.
- Age: between 18-60 years of age.

\section{Exclusion criteria:}

- Patient refusal

- Patients with contraindications to central neuroaxial blockade.

- Less than 18 more than 60 years old.

- Allergy to drugs used in the study.

- Respiratory, hepatic, renal impairment.

- Previous coronary heart disease, hypertension and diabetes.

- Neurological diseases.

\section{Preoperative assessment:}

- History (medical and surgical)

- Physical examination.

- Laboratory investigations (CBC, renal function tests, liver function tests. coagulation profile).

\section{Premedication:}

- Slow IV infusion of $50 \mathrm{mg}$ Ranitidine and $10 \mathrm{mg}$ Metoclopramide.

\section{Anesthetic technique:}

Intravenous access was established with a $18 \mathrm{G}$ Intravenous cannula and preloading was done with $15 \mathrm{ml} / \mathrm{kg}$ lactated ringer's solution. No sedative premedication was given.

Under all aseptic precautions, in sitting position with midline approach a lumbar puncture was done with a spinal needle (25G x 90 mm Uniever, Saitama, Japan).

After free flow of CSF, $3.5 \mathrm{ml}$ of $0.5 \%$ hyperbaric bupivacaine (Sunny pivacaine, Sunny medical, Bupivacaine HC $20 \mathrm{mg} /$ $4 \mathrm{ml}$ ) plus $0.4 \mathrm{ml}$ of saline $0.9 \%$ in control group. $3.5 \mathrm{ml}$ of $0.5 \%$ hyperbaric bupivacaine (Sunny pivacaine, Sunny 
medical, Bupivacaine HC $20 \mathrm{mg} / 4 \mathrm{ml}$ ), plus $2 \mathrm{mg}$ of $0.5 \%$ midazolam (Dormicum, Roche, Swizerland, $5 \mathrm{mg} / \mathrm{ml}$ ) in study group.

All patients were transferred from the post-anesthesia care unit to the surgical ward unless surgical practice required intensive care observation. Adjuvant analgesics such as ketorolac, and paracetamol were allowed at the discretion of the anesthesia pain service.

Basic monitoring for all patients (5 leads ECG, NIBP, pulse oximetry, capnography for endtidal $\mathrm{CO}_{2}$, and temperature monitoring by (Colin Bp- 608 Evolution)) monitor Manufactured by OMRON HEALTH CARE Co. Ltd (Japan).

\section{Data collection:}

- Demographic data: (age, gender, weight, height).

- Hemodynamic data:

- Mean arterial blood pressure.

- Heart rate.

- $\quad$ Primary outcome:

Evaluate the effect of intra thecal midazolam combined with bupivacaine on the duration of post-operative analgesia.

- Pain assessment will be done by Visual analogue scale $(0.0=$ no pain, $10.0=$ worst pain imaginable) immediately after intra thecal injection then every 30 minutes till 210 minutes.

- Onset of sensory block (min).

- Onset of motor block (min).

- Sensory block duration (min).

- Motor block duration (min).

- Secondary outcome:

Including nausea, vomiting.

\section{Sample size justification:}

Epi info version 1.4.3 program was efficiently used for calculations of sample size. Statistical calculator based on $95 \%$ confidence interval and power of the study $80 \%$ with $\alpha$ error $5 \%$. Assuming a drop out ratio of $5 \%$, the sample size was set as 60 cases in the study group.

\section{Statistical analysis:}

Data were analyzed using (IBM SPSS Statistics for Windows, Version 20.0. Armonk, NY: IBM Corp.). Numerical data were expressed as mean and standard deviation or median, and range as appropriate. Qualitative data were expressed as frequency and percentage. Chi-square test was used to examine the relation between qualitative variables. For quantitative data, comparison between two groups was done using t-test or Mann-Whitney test. P-value $\leq 0.05$ was considered significant.

\section{RESULTS}

There was no statistically significant difference in demographic and clinical data among the two groups (Table 1). 
Table (1): Comparison between groups according to demographic and clinical data

\begin{tabular}{|l|c|c|c|}
\hline \multicolumn{1}{|c|}{ Groups } & $\begin{array}{c}\text { Bupivacaine } \\
\text { only group } \\
\text { Demographic data }\end{array}$ & $\begin{array}{c}\text { Bupivacaine } \\
\text { midazolam } \\
\text { group (N=30) }\end{array}$ & P-value \\
\hline Age (years) & $34.17 \pm 7.2$ & $32.9 \pm 6.43$ & 0.474 \\
\hline Gender & $17(56.7 \%)$ & $12(40 \%)$ & \multirow{2}{*}{0.196} \\
\hline Female & $13(43.3 \%)$ & $18(60 \%)$ & 0.743 \\
\hline Male & $85.26 \pm 5.39$ & $84.77 \pm 6.12$ & 0.340 \\
\hline Weight (kg) & $176.33 \pm 7.56$ & $178.08 \pm 6.50$ & \\
\hline Height $(\mathbf{c m})$ &
\end{tabular}

There was no statistically significant difference in onset of sensory block and onset of motor block among the two groups (Table 2).

Table (2): Comparison between groups according to onset of sensory block and onset of motor block

\begin{tabular}{|c|c|c|c|c|}
\hline Parameters & $\begin{array}{c}\text { Onset of } \\
\text { sensory block } \\
\text { (min.) }\end{array}$ & $\begin{array}{c}\text { P-value } \\
\text { of Onset } \\
\text { of sensory }\end{array}$ & $\begin{array}{c}\begin{array}{c}\text { Onset of } \\
\text { motor block } \\
(\text { min. })\end{array} \\
\end{array}$ & $\begin{array}{l}\text { P-value } \\
\text { of Onset of } \\
\text { motor block }\end{array}$ \\
\hline Grot & Mean \pm SD & block & Mean \pm SD & \\
\hline $\begin{array}{c}\text { Bupivacaine only } \\
\text { group } \\
(\mathbf{N}=\mathbf{3 0})\end{array}$ & $1.55 \pm 0.48$ & \multirow{2}{*}{0.940} & $2.46 \pm 0.53$ & \multirow{2}{*}{0.601} \\
\hline $\begin{array}{c}\text { Bupivacaine } \\
\text { midazolam group } \\
(\mathrm{N}=30)\end{array}$ & $1.56 \pm 0.55$ & & $2.53 \pm 0.5$ & \\
\hline
\end{tabular}

There was no statistically significant difference in Mean Arterial Blood Pressure at Baseline, 5 min., 10 min., 15 min., 20 min., 30 min., 60 min., 120 min., and $180 \mathrm{~min}$. among the two groups (Table 3).

Table (3): Comparison between groups according to Mean Arterial Blood Pressure (MAP)

\begin{tabular}{|c|c|c|c|c|c|c|c|}
\hline \multirow{2}{*}{ Groups } & \multicolumn{3}{|c|}{$\begin{array}{c}\text { Bupivacaine only } \\
\text { group } \\
\text { MAP }\end{array}$} & Mean & \pm & \multicolumn{3}{c|}{$\begin{array}{c}\text { Bupivacaine midazolam } \\
\text { group } \\
(\mathbf{N = 3 0})\end{array}$} & \multirow{2}{*}{ P-value } \\
\cline { 2 - 7 } & $\mathbf{3}$ & SD & Mean & \pm & SD & \\
\hline Baseline & 95.7 & \pm & 5.76 & 94.12 & \pm & 6.8 & 0.335 \\
\hline 5 min. & 85.9 & \pm & 6.56 & 84.53 & \pm & 5.36 & 0.379 \\
\hline 10 min. & 86.15 & \pm & 7.65 & 83.82 & \pm & 4.96 & 0.167 \\
\hline 15 min. & 87.5 & \pm & 7.16 & 87.01 & \pm & 5.34 & 0.764 \\
\hline 20 min. & 88.05 & \pm & 8.06 & 86.3 & \pm & 5.57 & 0.332 \\
\hline 30 min. & 89.2 & \pm & 7.95 & 87.45 & \pm & 6.11 & 0.343 \\
\hline 60 min. & 89.35 & \pm & 8.58 & 88.11 & \pm & 6.94 & 0.540 \\
\hline 120 min. & 90.75 & \pm & 7.53 & 88.75 & \pm & 5.65 & 0.249 \\
\hline 180 min. & 93.2 & \pm & 7.16 & 91.1 & \pm & 6.54 & 0.240 \\
\hline
\end{tabular}


There was no statistically significant difference in Heart rate at Baseline, 5 min., 10 min., 15 min., 20 min., 30 min.,
$60 \mathrm{~min}$. and $120 \mathrm{~min}$. among the two groups (Table 4).

Table (4): Comparison between groups according to heart rate (HR)

\begin{tabular}{|c|c|c|c|c|c|c|c|}
\hline \multirow{2}{*}{ Groups } & \multicolumn{3}{|c|}{$\begin{array}{c}\text { Bupivacaine only } \\
\text { Group (N=30) }\end{array}$} & \multicolumn{3}{c|}{$\begin{array}{c}\text { Bupivacaine midazolam } \\
\text { group (N=30) }\end{array}$} & \multirow{2}{*}{ P-value } \\
\cline { 2 - 7 } HR & Mean & \pm & SD & Mean & \pm & SD & \\
\hline Baseline & 100.77 & \pm & 8.90 & 98.66 & \pm & 9.06 & 0.367 \\
\hline 5 min. & 102.8 & \pm & 9.02 & 101.45 & \pm & 8.23 & 0.547 \\
\hline 10 min. & 98.95 & \pm & 8.93 & 96.35 & \pm & 8.97 & 0.265 \\
\hline 15 min. & 93.94 & \pm & 8.46 & 92.34 & \pm & 8.33 & 0.466 \\
\hline 20 min. & 90.65 & \pm & 8.05 & 89.7 & \pm & 7.14 & 0.630 \\
\hline 30 min. & 87.45 & \pm & 8.77 & 86.23 & \pm & 7.12 & 0.556 \\
\hline 60 min. & 86.6 & \pm & 9.34 & 85.6 & \pm & 7.59 & 0.650 \\
\hline 120 min. & 85.25 & \pm & 9.18 & 84.1 & \pm & 6.75 & 0.582 \\
\hline
\end{tabular}

There was a statistically significant difference in duration of sensory block and there was no statistically significant difference in duration of motor block among the two groups (Table 5).

Table (5): Comparison between groups according to duration of sensory block and duration of motor block

\begin{tabular}{|c|c|c|c|c|}
\hline \multirow{2}{*}{ Parameters } & $\begin{array}{c}\text { Duration of } \\
\text { sensory } \\
\text { block (min.) }\end{array}$ & \multirow{2}{*}{$\begin{array}{c}\text { P-value } \\
\text { of Duration } \\
\text { of sensory } \\
\text { block. }\end{array}$} & $\begin{array}{c}\text { Duration of } \\
\text { motor block } \\
\text { (min.) }\end{array}$ & $\begin{array}{c}\text { P-value of } \\
\text { Duration } \\
\text { of motor } \\
\text { block. }\end{array}$ \\
\cline { 2 - 2 } & Mean \pm SD & & Mean \pm SD & \\
\cline { 1 - 2 } $\begin{array}{c}\text { Bupivacaine only } \\
\text { group } \\
\text { (N=30) }\end{array}$ & $120.0 \pm 31.54$ & & $116.51 \pm$ & \\
\cline { 1 - 1 } $\begin{array}{c}\text { Bupivacaine } \\
\text { midazolam group } \\
(\mathbf{N}=30)\end{array}$ & $152.5 \pm 20.44$ & \multirow{2}{*}{$<0.001$} & 19.54 & \multirow{2}{*}{0.126} \\
& & $123.57 \pm 15.1$ & \\
\hline
\end{tabular}

There was a statistically significant difference in VAS at $30 \mathrm{~min} ., 60 \mathrm{~min} ., 90$ min., 120 min., 150 min., 180 min. and
210 min. among the two groups when pvalue was $<0.001$ (Table 6). 
Table (6): Comparison between the two groups according to mean post-operative visual analogue scale (VAS)

\begin{tabular}{|c|c|c|c|c|c|}
\hline \multirow{2}{*}{ Groups } & \multicolumn{2}{|c|}{$\begin{array}{c}\text { Bupivacaine only } \\
\text { Group (N=30) }\end{array}$} & \multicolumn{2}{c|}{$\begin{array}{c}\text { Bupivacaine } \\
\text { midazolam group } \\
\text { (N=30) }\end{array}$} & $\begin{array}{c}\text { Mann- } \\
\text { Whitney } \\
\text { test }\end{array}$ \\
\cline { 2 - 6 } & Range & Median & Range & Median & P-value \\
\hline 0 min. & $1-2$ & 2 & $1-2$ & 2 & 0.953 \\
\hline 30 min. & $2-5$ & 4 & $1-4$ & 3 & $<0.001$ \\
\hline 60 min. & $2-6$ & 4 & $1-4$ & 2 & $<0.001$ \\
\hline 90 min. & $2-6$ & 4 & $1-3$ & 2 & $<0.001$ \\
\hline 120 min. & $2-6$ & 4 & $1-4$ & 2 & $<0.001$ \\
\hline 150 min. & $2-6$ & 4 & $1-3$ & 3 & $<0.001$ \\
\hline 180 min. & $2-5$ & 3 & $1-4$ & 2 & $<0.001$ \\
\hline 210 min. & $1-4$ & 3 & $1-3$ & 1 & $<0.001$ \\
\hline
\end{tabular}

There was no statistically significant difference in complications among the two groups (Table 7).

Table (7): Comparison between the two groups according to complications

\begin{tabular}{|c|c|c|c|c|c|}
\hline \multirow{2}{*}{ Groups } & \multicolumn{2}{|c|}{$\begin{array}{c}\text { Bupivacaine only } \\
\text { Group (N=30) }\end{array}$} & \multicolumn{2}{c|}{$\begin{array}{c}\text { Bupivacaine } \\
\text { midazolam } \\
\text { group (N=30) }\end{array}$} & Chi-square \\
\cline { 2 - 6 } & $\mathrm{N}$ & $\%$ & $\mathrm{~N}$ & $\%$ & P-value \\
\hline Nomplications & 16 & 53.3 & 18 & 60.0 & 0.602 \\
\hline Vomiting & 4 & 13.3 & 5 & 16.7 & 0.718 \\
\hline
\end{tabular}

\section{DISCUSSION}

Intrathecal midazolam has been shown to have analgesic properties and potentiates the effects of intrathecal local anaesthetics (Shadangi et al., 2011).

The mechanism by which midazolam provides analgesia has been explored in several studies (Shadangi et al., 2011). Some of which suggest that intrathecal midazolam is involved in the release of an endogenous opioid acting at spinal delta receptors (Shadangi et al., 2011). Therefore, adding intrathecal midazolam may potentiate the antinociceptive effect of morphine -like agents (Stuart, 2011). Some suggest that the mechanism of action of midazolam indirect and is related to GABA accumulation and its affinity to benzodiazepine receptor. Two separate receptors for GABA and benzodiazepine are coupled to a common chloride channel. It increases the frequency of chloride channel opening. Occupation of both the receptors causes membrane hyperpolarization and neuronal inhibition (De Paula et al., 2015).

We used $2 \mathrm{mg}$ midazolam as an additive to bupivacaine for intrathecal administration, as most studies agree that 1-2 mg intrathecal midazolam is safe and efficacious (Shadangi et al., 2011).

In our study, the duration of sensory blockade was prolonged in the midazolam group, which is comparable to the results of previously reported studies.

Intrathecal midazolam $2 \mathrm{mg}$ provided a moderate prolongation effect on 
postoperative analgesia as compared to 1 mg midazolam when used as an adjunct to bupivacaine in patients undergoing caesarean delivery (Bharti et al., 2015). However, the postoperative pain scores were lower in patients who received intrathecal midazolam $(1 \mathrm{mg})$ along with bupivacaine (Bhure et al., 2012).

The duration of postoperative analgesia was significantly prolonged with the addition of intrathecal midazolam and that the effect was dose-dependent (Oliveira Júnior et al., 2016).

In our study, there were no significant difference between the two groups as regard the duration of motor block, contrasted with a study, which found the duration of motor blockade to be prolonged in the midazolam group compared with the control group (Mohsin and Kumari 2016), the differences in these results may be due to the difference in number of patients between the two studies, age group in both studies or concentrations of injected drugs.

In our study, the duration of postoperative analgesia was longer in the bupivacaine midazolam group compared to the bupivacaine only group, but onset of sensory block in the bupivacaine only group and in bupivacaine midazolam group showed no significant difference.

In our study, there were no statistically significant difference in the two groups as regard postoperative nausea and vomiting, although $1 \mathrm{mg}$ and $2 \mathrm{mg}$ intrathecal midazolam has been reported to decrease postoperative nausea and vomiting (Shadangi et al., 2011), the differences in these results may be due to the difference in number of patients between the two studies, age group in both studies.

\section{CONCLUSION}

The addition of midazolam to bupivacaine in spinal anaesthesia resulted in prolonged postoperative analgesia with no significant increase in the duration of motor block.

\section{REFERENCES}

1. Bharti, N., Batra, Y. K. and Negi, S. L. (2015): Efficacy of intrathecal midazolam versus fentanyl for endoscopic urology surgery. Southern African Journal of Anaesthesia and Analgesia, 21(2): 31-34.

2. Bhure, A., Kalita, N., Ingley, P. and Gadkari, C. P. (2012): Comparative study of intrathecal hyperbaric Bupivacaine with Clonidine, Fentanyl and Midazolam for quality of anaesthesia and duration of post-operative pain relief in patients undergoing elective caesarean section. People's J Sci Res., 5(1): 1923.

3. Cowen, R., Stasiowska, M. K., Laycock, H. and Bantel, C. (2015): Assessing pain objectively: the use of physiological markers. Anaesthesia, 70(7): 828-847.

4. De Paula, N. C., Cordeiro, K. C. A., de Melo Souza, P. L., Nogueira, D. F., e Sousa, D. B. D. S., Costa, M. B. and de Oliveira, V. (2015): Biosynthesis of human diazepam and clonazepam metabolites. Bioorganic \& Medicinal Chemistry Letters, 25(5): 10261029 .

5. Kamali, A., Shokrpour, M., Vatanpour, K. and Eraghi, M. (2012): Midazolam versus neostigmineadding to lidocaine in post operation pain in colporrhaphy surgery in spinal anesthesia. Journal of Family and Reproductive Health, 79-83.

6. Mohsin, M. and Kumari, R. (2016): Observation on analgesic efficacy and adverse effects of intrathecal administration of bupivacaine versus bupivacaine-midazolam combination in lower limb surgeries in a tertiary care hospital. International Journal of Research in Medical Sciences, 4(3): 881-886.

7. Oliveira Júnior, J. O. D., Corrêa, C. F. and Ferreira, J. A. (2016): Invasive treatment to 


\section{AHMED THARWAT MOSALLAM ASFOUR et al.,}

control neuropathic pain. Revista Dor, 17: 98106.

8. Shadangi, B. K., Garg, R., Pandey, R. and Das, T. (2011): Effects of intrathecal midazolam in spinal anaesthesia: a prospective randomised case control study. Singapore Medical Journal, 52(6): 432-435.

9. Stein, C. (2018): New concepts in opioid analgesia. Expert opinion on investigational drugs, 27(10): 765-775.
10. Stuart, P. (2011): Novel additives to neuraxial blockade. Southern African Journal of Anaesthesia and Analgesia, 17(1): 86-89.

11. Tesfaye, S., Boulton, A. J. and Dickenson, A. H. (2013): Mechanisms and management of diabetic painful distal symmetrical polyneuropathy. Diabetes care, 36(9): 24562465 . 
در اسة مقارنة بين تأثير الحقن تحت الأم العنكبوتية لعقار

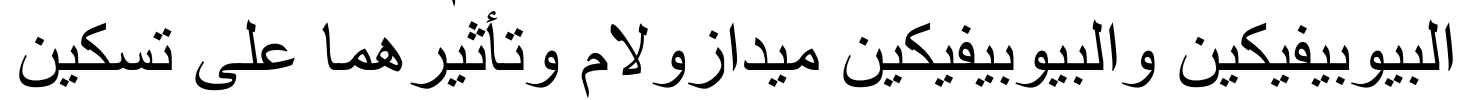
الألم بعد العملية الجر احية.

أحمد ثروت مسلم عصفور، منى هانم عبد الغفار أحمد، نصر عبد العزيز محمد سعد الإه قسم التخدير والرعاية المركزة، كلية الطب، جامعة الازهر

E-mail: $\underline{\text { ahmedasfour551@gmail.com }}$

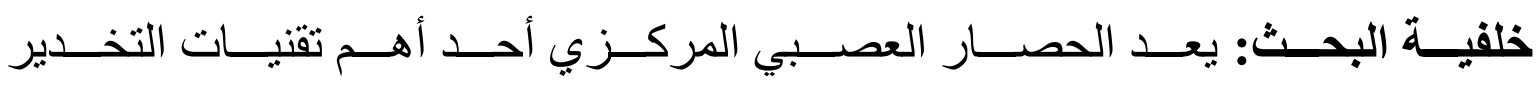

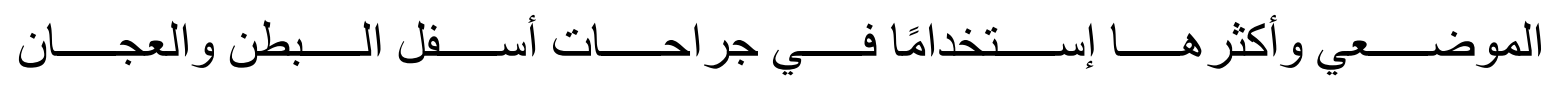

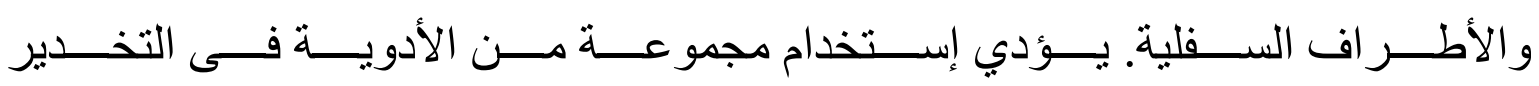

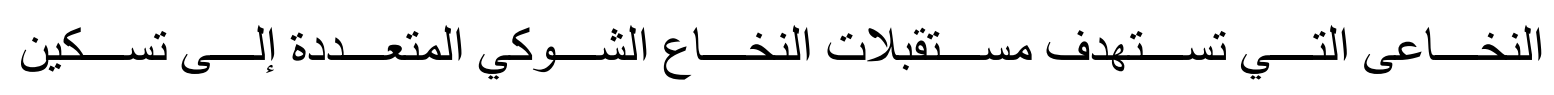

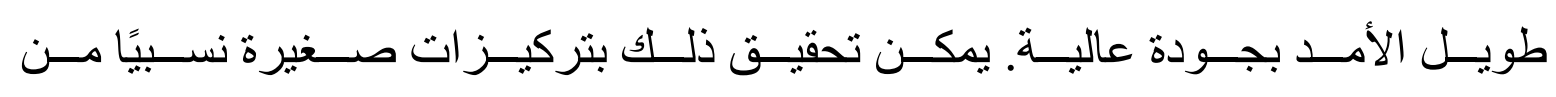

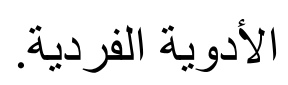

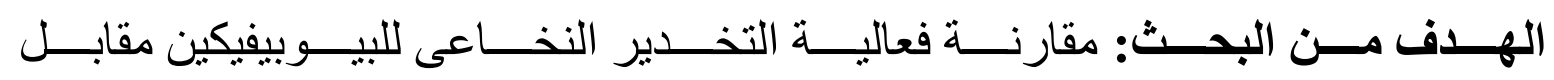
بيو بيفيكين ميدازو لام على تسكين الألم بعد الجراحة.

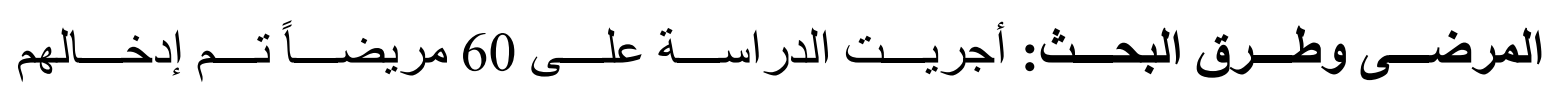

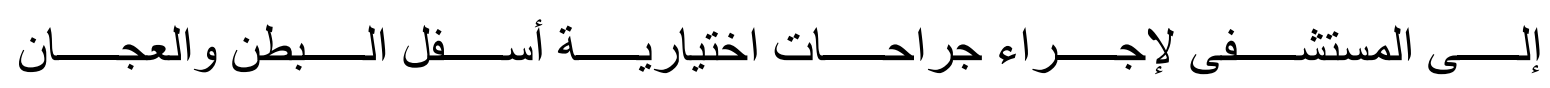

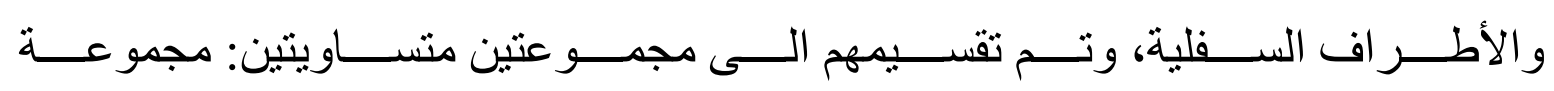

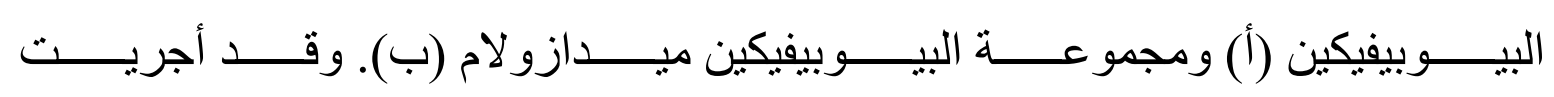

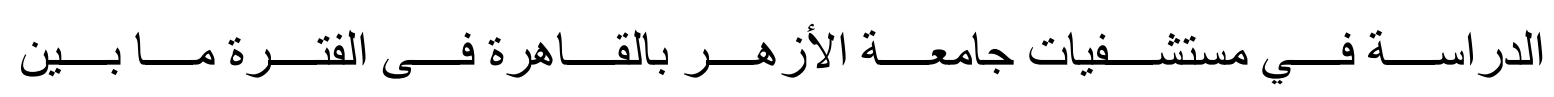
أغسطس 2019 إلى يوليو 2020.

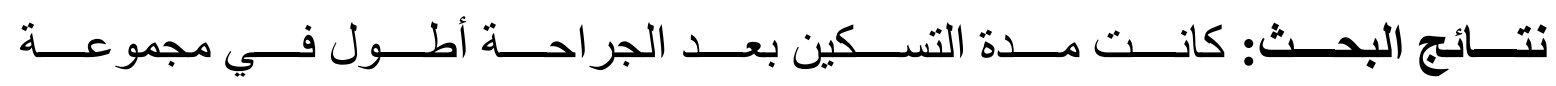

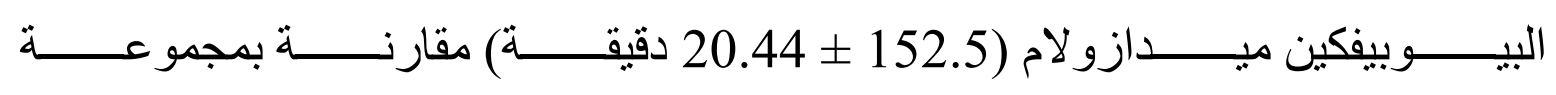

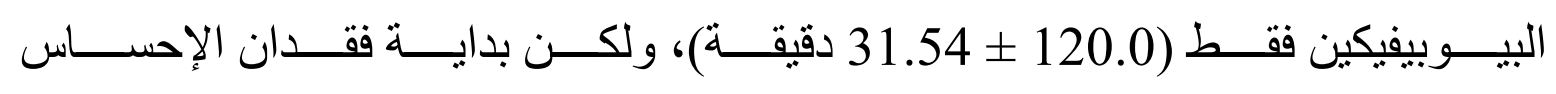




\section{AHMED THARWAT MOSALLAM ASFOUR et al.,}

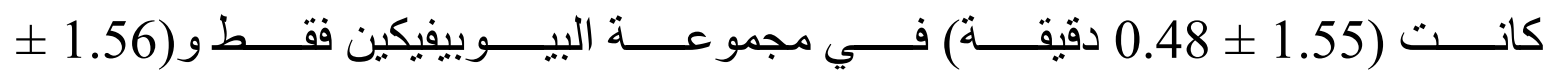

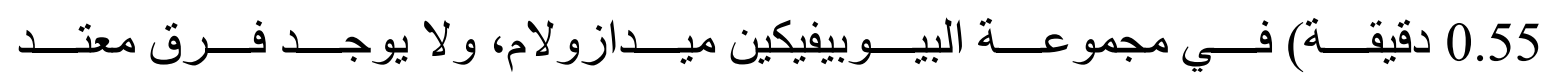

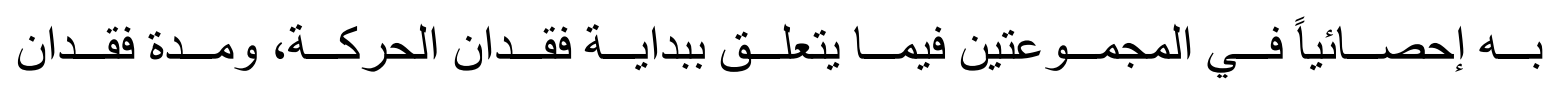
الحركة، والتأثير على الغثيان و القيء بعد العملية الجر احية.

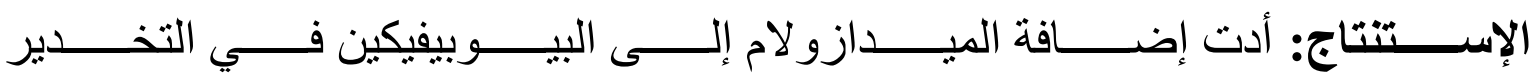

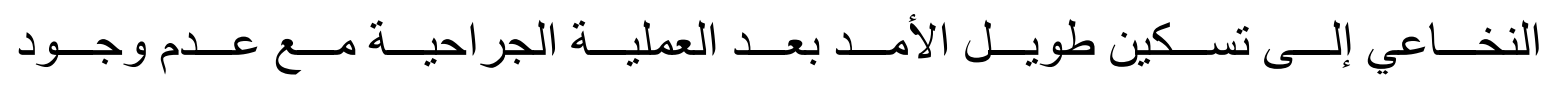
زيادة كبيرة فى مدة التوقف الحركى.

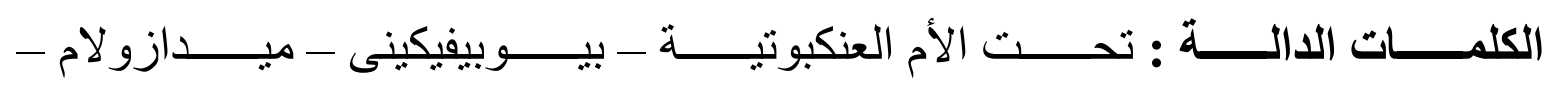
تسكين الألم بعد الجراحة . 